\title{
Deteksi Natrium/Iodide Symporter (NIS) pada Galur Sel Kanker Payudara SKBR3 dengan Imunositofluoresens
}

\author{
Aisyah Elliyanti, ${ }^{1}$ Tenny Putri Wikayani, ${ }^{2}$ Noormartany, ${ }^{3}$ Johan S. Masjhur, ${ }^{4}$ Tri Hanggono Achmad ${ }^{5}$ \\ ${ }^{1}$ Bagian Fisika Kedokteran Fakultas Kedokteran Universitas Andalas, ${ }^{2}$ Rumah Sakit Pendidikan Fakultas \\ Kedokteran Universitas Padjadjaran, ${ }^{3}$ Departemen Patologi Klinik Fakultas Kedokteran Universitas Padjadjaran/ \\ Rumah Sakit Dr. Hasan Sadikin Bandung, ${ }^{4}$ Departemen Kedokteran Nuklir Fakultas Kedokteran Universitas \\ Padjadjaran/Rumah Sakit Dr. Hasan Sadikin Bandung, ${ }^{5}$ Departemen Biokimia Fakultas Kedokteran Universitas \\ Padjadjaran
}

\begin{abstract}
Abstrak
Galur sel SKBR3 adalah model kanker payudara positif human epidermal growth factor receptor2 (HER2). Pemberian kemoterapi memperlihatkan respons lengkap hanya pada 50\% pasien kanker payudara dengan tipe positif HER2. Kemampuan jaringan tumor menangkap dan mengakumulasi iodium radioaktif dihubungkan dengan ekspresi natrium/iodide symporter (NIS). Tujuan penelitian ini adalah menilai ekspresi dan distribusi NIS pada galur sel SKBR3 serta menilai efek induksi epidermal growth factor (EGF) pada ekspresi NIS menggunakan imunositofluoresens-ISF. Penelitian ini dilakukan di Laboratorium Kultur Sel, Fakultas Kedokteran Universitas Padjadjaran (FKUP) mulai bulan September 2013 sampai dengan April 2014. Sel SKBR3 ditumbuhkan pada plat kultur dan ditunggu hingga konfluen 70\%. Sel dibagi atas dua kelompok, yaitu kelompok yang diberi induksi dan kontrol. Induksi EGF diberikan dengan dosis $50 \mathrm{ng} / \mathrm{mL}$. Pemeriksaan ISF menggunakan antibodi primer rabbit polyclonal antibody anti NIS dan antibodi sekunder goat anti rabbit IgG polyclonal antibody. Data hasil pengamatan dinilai secara semikuantitatif. Natrium/iodide symporter tampak terekspresi dan terdistribusi di sitoplasma. Sel yang diinduksi dengan EGF memperlihatkan peningkatan ekspresi NIS di sitoplasma dan distribusinya di membran sel secara bermakna. Sel SKBR3 mengekspresikan NIS yang terdapat di sitoplasma. Induksi EGF meningkatkan ekspresi NIS dan distribusinya di membran sel. Temuan ini dapat mengarah potensi kemampuan sel kanker payudara menangkap dan mengakumulasikan iodium radioaktif. [MKB. 2016;48(1):15-8]
\end{abstract}

Kata kunci: Ekspresi NIS , galur sel SKBR3, kanker payudara, imunositofluoresens

\section{Detection of Natrium/Iodide Symporter (NIS) in SKBR-3 Breast Cancer Cell Line Using Immunocytofluoresence}

\begin{abstract}
SKBR-3 cell line is a breast cancer model for human epidermal growth factor receptor2 (HER2) positive. Only 50\% of patients of this type have fully responded to chemotherapy. Natrium iodide symporter expression correlates with the uptake and ability of cells to accumulate radioiodine. The aim of this study was to examine natrium/ iodide symporter (NIS) expression and its distribution with and without epidermal growth factor (EGF) treatment using immunocytofluoresence (ICF). This study was conducted at the Cell Culture Laboratory, Faculty of Medicine, Universitas Padjadjaran from September 2013 to April 2014. SKBR3 cells were cultured until 70\% confluent. Cells were then divided into two groups: treatment group and control group. The treatment group was treated with EGF $50 \mathrm{ng} / \mathrm{mL}$. Cells were incubated with primary antibody rabbit polyclonal antibody anti-NIS, and then were followed with secondary-antibody goat polyclonal antibody to rabbit. Data from the observation were then assessed semi-quantitatively. Natrium/iodide symporter was seen to be expressed and distributed in the cytoplasm. Cells induced by EGF showed significant increase in NIS expression in cytoplasm and its distribution in cell membrane. It is concluded that the SKBR3 cells express NIS in cytoplasm and that EGF induction increases NIS expression and distribution in cell membrane. This finding leads to a potential ability of breast cancer cells to uptake and accumulate radioiodine. [MKB. 2016;48(1):15-8]
\end{abstract}

Key words: Breast cancer, cell line SKBR-3, immunocytofluoresence, NIS expression

Korespondensi: Aisyah Elliyanti, dr., Sp KN, M. Kes, Bagian Fisika Kedokteran Fakultas Kedokteran Universitas Andalas Jalan Perintis Kemerdekaan, Padang 25127, Sumatera Barat, mobile 08126636987, e-mail aelliyanti@yahoo.com 


\section{Pendahuluan}

Kemajuan pesat pada penelitian dasar berbasis molekuler telah memberi dampak yang baik bagi pengelolaan penyakit tidak terkecuali pada penyakit kanker. Untuk itu, riset ekperimental menggunakan berbagai jenis galur sel merupakan model riset eksperimental yang efektif untuk menyelidiki subtipe suatu penyakit. Galur sel SKBR3 merupakan model kanker payudara yang positif mengekspresikan HER2. ${ }^{1}$ Tipe positif human epidermal growth factor receptor 2 (HER2) merupakan 25-30\% dari keseluruhan kasus pada kanker payudara. Ekspresi HER2 dihubungan dengan penyakit yang lebih agresif, angka kekambuhan yang tinggi, dan juga angka harapan hidup yang memendek. Hanya sebanyak $50 \%$ pasien kelompok ini yang memperlihatkan respons lengkap pada pemberian kemoterapi. ${ }^{2,3}$

Pada kanker tiroid kemampuan jaringan tumor menangkap dan mengakumulasi iodium radioaktif dipengaruhi oleh ekspresi natrium/ iodide symporter (NIS) yang terdistribusi pada membran sel (NIS fungsional). Natrium/iodide symporter merupakan glikoprotein yang terdiri atas 13 segmen transmembran, membawa dua ion natrium $\left(\mathrm{Na}^{+}\right)$dan satu ion iodida $(\mathrm{I})$ dari ekstraseluler ke intraseluler melawan gradien konsentrasi I' yang dipertahankan oleh pompa $\mathrm{Na}^{+} / \mathrm{K}^{+}$-ATPase melintasi membran basolateral. ${ }^{4}$

Tingkat ekpresi NIS fungsional merupakan prediktor kemangkusan penggunaan iodium radioaktif padakanker tiroid..$^{10}$ Beberapa jaringan ekstratiroid seperti kelenjar payudara dan kanker payudara dilaporkan mengekspresikan NIS. ${ }^{5}$ Penemuan ini memberikan pengaruh besar pada peran NIS, dari sebagai protein pembawa kepada peran diagnosis dan terapi. Laporan mengenai ekspresi NIS pada kanker payudara mampu menjadi potensi pemberian iodium radioaktif pada kanker payudara terutama pada kasus yang resisten dengan pengobatan hormonal dan kemoterapi.

Epidermal growth factor (EGF) dilaporkan mampu meningkatkan ekspresi NIS terhadap membran sel T47D melalui jalur mitogenactivated protein kinase (MAPK) dan dapat meningkatkan tangkapan iodium radioaktif. Jalur ini memainkan peranan penting pada proses transmisi sinyal ekstraseluler yang berkenaan dengan stimuli pengaturan pertumbuhan sel, diferensiasi, migrasi, dan kelangsungan hidup sel. ${ }^{6}$

Natrium/iodide symporter (NIS) merupakan suatu glikoprotein. Deteksi ekspresi protein berdasarkan ikatan antigen dengan antibodi memakai fluoresens dari spesimen sel dikenal dengan suatu pemeriksaan imunositofluoresens. Penggunaan fluoresens bertujuan meningkatkan sensitivitas dalam mendeteksi protein spesifik atau molekul lainnya melalui ikatan spesifik antara antibodi dan antigen. Ikatan antibodi dan juga antigen tersebut selanjutnya akan berikatan dengan fluoropore pada pewarnaan langsung/ dengan antibodi sekunder yang terkonyugasi dengan fluorophore atau fluorochome pada pewarnaan tidak langsung. Hasil perwarnaan dianalisis dengan mikroskop fluoresens. ${ }^{7}$

Tujuan penelitian ini adalah menilai ekspresi dan distribusi NIS pada galur sel SKBR3 yang merupakan model kanker payudara tipe positif HER2 serta menilai efek EGF sebagai induktor pada ekspresi dan distribusi NIS fungsional.

\section{Metode}

Penelitian ini dilakukan di Laboratorium Kultur Sel, Fakultas Kedokteran Universitas Padjadjaran (FKUP) mulai bulan September 2013 sampai dengan April 2014. Sel ditanam pada plat kultur yang sudah dilapisi dengan coverslip dan ditunggu hingga konfluens $70 \%$. Sel SKBR3 didapat dari American tissue culture collection (ATCC) dan ditumbuhkan dalam media McCoy 5A. Ke dalam media ditambahkan fetal bovine serum (FBS) $10 \%, 1 \%$ panstrep, dan $1 \%$ amphotericin B. Sel diinkubasi selama 24 jam dalam inkubator pada suhu $37^{\circ} \mathrm{C}$ dengan kosentrasi karbon dioksida $\left(\mathrm{CO}_{2}\right)$ 5\%. Selanjutnya, diberi induksi EGF 50 $\mathrm{ng} / \mathrm{mL}$ selama 24 jam, sedangkan sel yang dijadikan sebagai kontrol hanya ditambahkan media. Setelah masa induksi berakhir segera dilanjutkan dengan proses pada perwarnaan. Eksperimen dilakukan secara triplo.

Pewarnaan ISF yang dilakukan mengacu pada protokol pabrikan dengan sedikit modifikasi. Langkah pewarnaan dimulai dengan fiksasi sel mempergunakan paraformaldehyde $4 \%$ selama 15 menit. Selanjutnya, sel dicuci 3 kali dengan 1xPBS dingin, kemudian direndam selama 10 menit dalam tween $20(0,5 \%)$ selama 15 menit. Kemudian sel dicuci 3x5 menit dengan 1xPBS dan diteteskan dengan fluorescein-isothiocyanateprotein blocking agent (FITC-PBA). Selanjutnya, diteteskan antibodi primer dan diinkubasi selama satu malam pada suhu $4^{\circ} \mathrm{C}$, kemudian dicuci dengan PBS 3x5 menit dan diinkubasi dengan antibodi sekunder pada suhu kamar di tempat gelap selama 60 menit. Kontrol negatif hanya ditetesi antibodi sekunder. Pengamatan dilakukan dengan mempergunakan mikroskop 

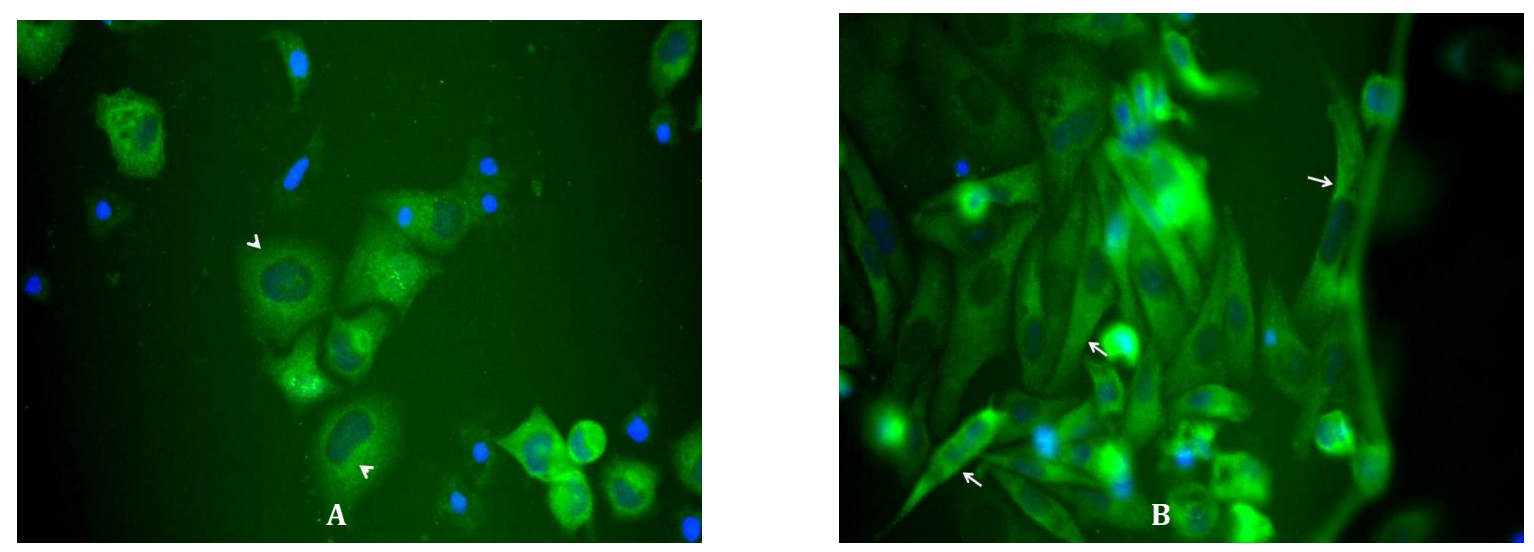

Gambar Ekspresi Protein Nis pada Sel SKBR3 Tampak Berwarna Hijau dan Inti Berwarna Biru

(A) Pada sel yang tidak diinduksi, tampak terekspresi NIS hanya di sitoplasma (kepala panah). (B) Induksi dengan EGF meningkatkan ekspresi protein NIS di sitoplasma dan membran sel (tanda panah tipis).

Gambar diambil dengan pembesaran 200 kali

fluoresens.

Data hasil pengamatan dinilai secara semikuantitatif, diambil dari lima lapang pandang secara acak dari setiap preparat. Nilai satu jika ekspresi protein NIS lemah pada sitoplasma saja, nilai dua jika ekspresi lemah sampai sedang pada sitoplasma dan membran sel, serta nilai tiga jika ekspresi kuat di sitoplasma dan membran. Data dianalisis menggunakan Mann-Whitney dengan $\mathrm{p}<0,05$ dianggap bermakna. Pada penelitian tidak ada implikasi etik karena subjek penelitian ini adalah galur sel.

\section{Hasil}

Ekspresi NIS tampak pada sel SKBR3 serta terdistribusi pada sitoplasma. Ekspresi NIS ratarata pada sel SKBR3 dinilai satu. Pada pemberian induksi EGF didapatkan peningkatan ekspresi dan distribusi NIS di membran sel (Gambar). Ekspresi NIS rata-rata sesudah induksi EGF dinilai tiga. Ekspresi dan distribusi NIS tersebut

Tabel Kategori Hasil Pemeriksaan Imunositofloresens pada Sel SKBR3

\begin{tabular}{lcc}
\hline Sampel Rata-rata & EGF & Kontrol \\
\hline Slide 1 & 3 & 1 \\
Slide 2 & 3 & 1 \\
Slide 3 & 3 & 1 \\
Rata-rata & 3 & 1 \\
SD & 0 & 0 \\
\hline
\end{tabular}

meningkat secara bermakna dengan induksi EGF $(\mathrm{p}<0,05 ;$ Tabel $)$.

\section{Pembahasan}

Secara molekular kanker payudara dapat dibagi secara umum dalam 5 (lima) klasifikasi, yaitu luminal A, luminal B, basal, positif HER2, dan normal. ${ }^{8,9}$ Kelompok positif HER2 merupakan 25-30\% kasus kanker payudara dan merupakan kelompok yang sensitif dengan pemberian kemoterapi, namun demikian hanya sekitar $50 \%$ pasien kelompok ini yang memperlihatkan respons lengkap pada pemberian kemoterapi. ${ }^{2,3}$

Ekpresi NIS fungsional pada membran sel kanker merupakan indikator kemampuan sel untuk menangkap iodium radioaktif. Sebagian besar kanker payudara (70-80\%) dilaporkan mengekspresikan NIS. Namun demikian, laporan mengenai tangkapan iodium radioaktif oleh sel kanker payudara yang sangat rendah. ${ }^{10}$ Pada penelitian in vitro menggunakan galur sel MCF7 yang merupakan model kanker payudara tipe luminal $\mathrm{A}$, induksi dengan asam retinoid mutlak diperlukan untuk mendapatkan ekspresi NIS. Penambahan hidrokortison dilaporkan dapat meningkatkan efek asam retinoid pada ekspresi NIS. ${ }^{11}$ Demikian pula pada galur sel T47D yang merupakan model kanker payudara tipe luminal A dilaporkan bahwa pemberian EGF mampu meningkatkan ekspresi NIS dan juga tangkapan iodium radioaktif. ${ }^{6}$

Epidermal growth factor merupakan salah satu agen farmakologi yang dapat mengaktifkan 
jalur kinase intraseluler melalui jalur mitogenactivated protein kinase (MAPK). Pemberian induksi EGF pada sel T47D dilaporkan mampu meningkatkan ekspresi NIS dan juga tangkapan iodium radioaktif. Transfeksi gen NIS disertai dengan pemberian EGF pada galur sel $\mathrm{HuH7}$ yang merupakan model hepatoseluler karsinoma dilaporkan meningkatkan tangkapan iodium radioaktif. ${ }^{12}$

Berbeda dengan laporan penelitian oleh Dohan dkk. ${ }^{11}$ bahwa pada galur sel MCF-7 mutlak diperlukan penambahan asam retinoid untuk mendapatkan ekspresi NIS. Pada penelitian ini, didapatkan ekspresi NIS pada sel SKBR3 tanpa induksi dan dengan induksi EGF, namun ekspresi NIS pada sel yang tidak dinduksi terdapat di sitoplasma. Sejalan dengan hasil penelitian dari Beyer dkk. ${ }^{13}$ pada jaringan kanker payudara yang diperiksa dengan imunohistokimia didapatkan ekspresi protein NIS sebagian besar terdapat di intraseluler. Pemberian EGF dapat meningkatkan ekspresi dan distribusi NIS di membran sel SKBR3. Ekspresi NIS pada membran ini dapat menjadikan NIS berpotensi sebagai kotranspor iodium radioaktif dari ekstraseluler ke intraseluler.

Simpulan, sel SKBR3 yang merupakan model sel kanker payudara tipe HER2 mengekspresikan protein NIS yang terdapat pada sitoplasma. Induksi EGF tersebut mampu meningkatkan ekspresi protein NIS fungsional di membran dan di sitoplasma. Temuan ini dapat menjadi potensi bagi sel kanker payudara terutama tipe positif HER2 untuk menangkap dan mengakumulasikan iodium radioaktif.

\section{Ucapan Terima Kasih}

Sdr Andani Eka Putra dari Bagian Mikrobiologi Fakultas Kedokteran Universitas Andalas dan Sdri Ikke Kristinah dari Rumah Sakit Limjati atas bantuannya pada proses troubleshooting.

\section{Daftar Pustaka}

1. Holliday DL, Speirs V. Choosing the right galur cell for breast cancer research. Breast Cancer Research. 2011:13(4);215.

2. O’Brien K, Cole SR, Tse CK, Perou CM, Carey LA, Foulkes WD, dkk. Intrinsic breast tumor subtypes, race, and long-term survival in the carolina breast cancer study. Clin Cancer Res. 2010;16(24):6100-10.
3. Reiner C, Yao C, Goris M, Ghosh M, Katznelson L, Nowles K. Endogenous NIS expression in triple-negative breast cancers. Ann Surg Oncol. 2009;16(4):962-8.

4. Hingorani M, Spitzweg C, Vassaux G, Newbold $\mathrm{K}$, Melcher A, Pandha H, dkk. The biology of the sodium iodide symporter and its potential for targeted gene delivery. Current Cancer Drug Targets. 2010;10(2):242-67.

5. Micali S, Bulotta S, Puppin C, Territo A, Navarra M, Bianchi G, dkk. Sodium iodide symporter (nis) in extrathyroidal malignancies: focus on breast and urological cancer. BMC Cancer. 2014:14:303.

6. Jung KH, Paik JY, Ko BH, Lee KH. Mitogenactivated protein kinase signaling enhances sodium iodide symporter function and efficacy of radioiodine therapy in non thyroidal cancer cell. J Nuclear Med. 2008; 49(12):1966-72.

7. Karp G. Cell and molecular biology, concepts and experimets. Edisi ke-7. Ottawa: John Wiley and Son's; 2013.

8. Prat A, Perou CM. Deconstracting the molecular portraits of breast cancer. Mol Oncol. 2011;5(1):5-23.

9. Lin CH, Liau JY, Lu YS, Huang CS, Lee WC, Kuo KT, dkk. Molecular subtypes of breast cancer emerging in young women in taiwan: evidence for more than just westernization as a reason for the disease in Asia. Cancer Epidemiol Biomarkers Prev. 2009;18(6):1807-14.

10. Kogai T, Brent GA. The sodium iodide symporter (NIS): regulation and approaches to targeting for cancer therapeutics. Pharmacol Ther. 2012;135(3):355-70.

11. Dohan O, De la Vieja A, Carrasco N. Hydrocortisone and purinergic signaling stimulate sodium/iodide symporter (nis)mediated iodide transport in breast cancer cell. Molecular Endocrinol. 2006;20(5): 1121-37.

12. Klutz K, Schaffert D, Willhauck MJ, Grunwald GK, Haase R, Wunderlich N, dkk. Epidermal growth factor receptor-targeted i-131therapy of liver cancer following systemic delivery of the sodium iodide symporter gene. Mol Ther. 2011;19(4):676-85.

13. Beyer SJ, Jimenez RE, Shapiro CL, Cho JY, Jhiang SM. Do Cell surface trafficking impairments account for variable cell surface sodium iodide symporter level in breast cancer?. Breast Cancer Res Treat. 2009;115(1):205-12. 